\title{
CORTOMETRAJES, CORTOCIRCUITOS Y ALGUNOS (ANTI) RECUERDOS LITERARIOS EN LA OBRA (Y LA VIDA) DE NICANOR PARRA*
}

\author{
Javier Pinedo \\ Universidad de Talca \\ jpinedo@utalca.cl
}

RESUMEN / ABSTRACT

El artículo se pregunta por la relación entre poesía y pensamiento, y propone una génesis particular de la literatura de Nicanor Parra desde ciertos recuerdos que afectan, según su propia confesión, a su creatividad y que están en el origen de una escritura antirretórica y en oposición a las formas anteriores, que con la aparición de la antipoesía pasaron a ser leídas como expresiones convencionales del quehacer poético en Chile.

Palabras clave: Nicanor Parra, antipoesía, pensamiento, recuerdos.

The article asks about the relationship between poetry and thinking, and proposes a particular genesis of Nicanor Parra literature from certain memories that affect, according to his own confession to their creativity and which are at the origin of an anti-rhetorical writing and in opposition to the previous forms, which came to be read as conventional expressions of poetic activity in Chile with the emergence of the anti-poetry.

KEY WORD: Nicanor Parra, antipoetry, thoughts, memories.

Este artículo forma parte del proyecto de investigación: "Los años 60 en Chile: representaciones conceptuales y simbólicas de una década, sus debates intelectuales y función de la literatura en una sociedad en transición”. Fondecyt, Chile, $\mathrm{N}^{\circ} 1150762$. 


\section{INTRODUCCIÓN}

Consideramos las obras literarias como lugares privilegiados para el conocimiento de la realidad, tema que ha cruzado las reflexiones teóricas desde Aristóteles hasta Heidegger, Sartre, Steiner, Rancière y otros autores que han recapacitado sobre la relación pensamiento, palabra, mundo.

En este sentido, la correspondencia poesía-pensamiento resulta vital al estudiar la obra de Nicanor Parra, debido a su carácter narrativo que se expresa con fórmulas breves y directas como silogismos que, sin embargo, no siempre llegan a resultados lógicos. Una poesía muy cercana al mundo real y especialmente a la política chilena contingente en el momento de su escritura. Lo anterior no ha impedido al antipoema alcanzar momentos de gran altura literaria.

Esta forma de expresión (estética) la analizamos desde algunos recuerdos $\mathrm{y}$ vivencias en los cuales el antipoeta reflexiona, observa el mundo y lo traduce en imágenes literarias. Queremos saber (intuitivamente) la manera cómo Parra construye sus poemas, en su síntesis de matemático, físico y poeta, pero también a través de algunos recuerdos que nos dicen mucho de su actitud ante la literatura (y la vida).

\section{PENSAR EN “CORTOMETRAJES”. ESCRIBIR CON IMÁGENES}

Todo comienza hacia mediados de los años 90, con una invitación a Nicanor Parra para una lectura suya a los estudiantes de la Universidad de Talca.

La noche anterior al recital cenamos con él y un grupo de profesores de la Universidad, y Parra estaba obsesionado con las paradojas o aporías de Zenón de Elea, el filósofo griego del 400 antes de Cristo que buscaba establecer los límites entre la verdad y la falsedad, tema que se estructura, nos dijo, en cuatro aspectos: "Contra la pluralidad como estructura de lo real"; "Contra la validez del espacio"; "Contra la realidad del movimiento"; y "Contra la realidad del transcurrir del tiempo". Zenón habría planteado un total de 40 paradojas, de las cuales se han conservado nueve o diez en la Física de Aristóteles.

Pero, Zenón también postulaba una posición ética y cuando Dionisio le preguntó, en qué consiste la superioridad de la filosofía, respondió: “¡En el desprecio a la muerte!". 
La más conocida de las paradojas y que Parra aquella noche se dedicó a exponer y analizar una y otra vez, es la de "Aquiles y la Tortuga", según la cual un corredor veloz no podría nunca alcanzar a un corredor lento si el primero daba al segundo una ventaja en la partida.

Años más tarde Nicanor graficará este tema en uno de sus "Trabajos prácticos" (2011), reproduciendo un antiguo tocadiscos que gira sin avanzar a ninguna parte:

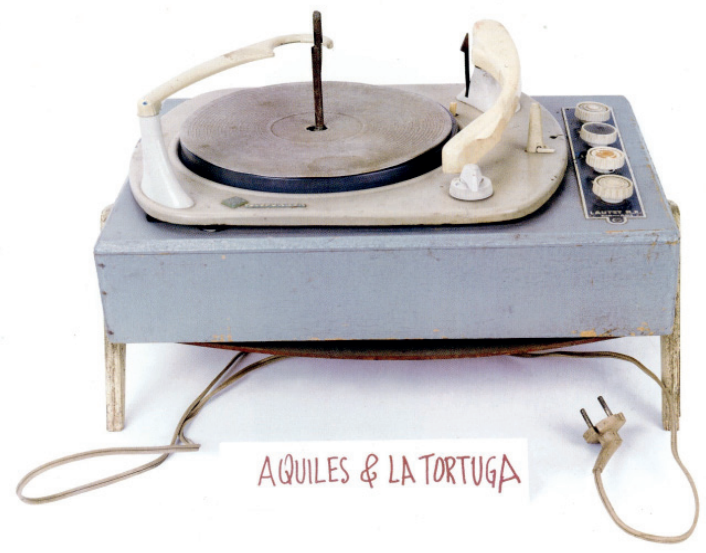

Hoy sabemos que en la práctica sí es posible vencer al que partió antes, según este esquema que no recuerdo si Parra lo mencionó o no, pero me gusta creer que lo tenía ya escrito o lo dibujó en un papel con la boca llena de risa.

$10+1+\frac{1}{10}+\frac{1}{100}+\frac{1}{1000}+\cdots=10 \sum_{n=0}^{\infty}\left(\frac{1}{10}\right)^{n}=\frac{10}{1-1 / 10}=\frac{10}{9 / 10}=\frac{100}{9}=11,11111 \ldots=11, \overline{1}$

Al concluir la cena, dejamos a Nicanor en el hotel con el compromiso de buscarlo por la mañana para ir a la Universidad. Cuando llegué al día siguiente, Parra estaba interferido por algo que lo intranquilizaba. Parecía molesto, se movía nervioso, ni siquiera había tomado desayuno y me dijo que el recital se suspendía. La razón: no había logrado dormir nada durante la noche. Zenón no lo había abandonado, estaba crispado y algo fuera de sí y me pidió que lo regresáramos a Las Cruces.

Eso es imposible, el salón está lleno de estudiantes y profesores, es tu primer recital postdictadura después de años de silencio, qué les vamos a decir. Él insistía, y cuando le pregunté qué había sucedido por la noche, me 
dijo que estaba enfermo de "cortometrajes", que le vienen a la mente y no lo dejan descansar: "Son imágenes en movimiento, pequeños cortometrajes, flash de historias verdaderas o imaginadas. Escenas sueltas de una película con voces y diálogos absurdos e incoherentes, de personas conocidas o no y que de pronto desaparecen. A veces son tan intensos esos "cortometrajes" que me toman el ánimo y no me dejan vivir, aparecen en cualquier momento sin aviso y se van como llegaron".

Tal vez la explicación le ayudó a recuperar el ánimo y al final accedió, el recital fue un éxito y todo concluyó bien. Nicanor se fue a Las Cruces, pero una parte de esa personalidad que cambió la poesía chilena del siglo $\mathrm{XX}$ quedó dando vueltas en mí. Pensé que esos cortometrajes podrían estar en el origen de un modo de funcionamiento mental particular y que ese "desorden" de las imágenes impulsadas por conflictivos recuerdos pudiera transformarse en un factor creativo y traducirse más tarde en poemas. Una estética basada en un desorden de la percepción que tiene su antecedente en Rimbaud quien en Cartas del Vidente (1871), había escrito: "Se trata de llegar a lo desconocido mediante el desorden de todos los sentidos". Y posteriormente en Una temporada en el infierno (1873) lo confirma: “Acabé por encontrar sagrado el desorden de mi espíritu". La gran diferencia es que mientras el francés intentaba ser "absolutamente moderno", el chileno desprecia absolutamente la modernidad.

¿Son las (intensas) imágenes literarias de sus poemas partes de esos cortometrajes, fotografías congeladas de una película mental con visiones, paisajes, rostros, palabras de un mundo real todavía no metaforizado? ¿Es el poema un conjunto de imágenes aisladas de una larga e incoherente película que es la vida en sociedad? ¿Piensa Parra desde esos cortometrajes como piensa un físico en una fórmula que traduce la realidad? ¿Es función de la poesía dar un orden literario a esa confusión mental anterior a la creación?

Me parece que no son las metáforas, más bien escasas, las que marcan la antipoesía, pues lo que nos impacta es la fuerza de sus imágenes en la construcción de una poesía visual. Poemas como crónicas de un presente que se fuga y una realidad sin lógica.

Hago como que miro los espejos

Un cliente estornuda a su mujer

Otro enciende un cigarro

Otro lee Las Últimas Noticias. 
¿Qué hay de poético en estos versos? ¿Por qué los calificamos de literatura? Lo más evidente es señalar la muda presencia del que observa en silencio desde una posición enajenada y distante. El primer verso lo define como un ser que miente para pasar inadvertido. Los otros tres son descripciones de una realidad ultracotidiana, como en una pintura de Edward Hooper y la fuerza de esos versos está en que no aspiran a ninguna trascendencia sino a la congelada tensión que ocultan ${ }^{1}$.

\section{ALGUNAS (BREVES) CONSIDERACIONES TEÓRICAS}

Esta manera de concebir (y construir) literatura es concordante con la aspiración de Parra de decirnos lo que NO espera de la poesía ("La poesía terminó conmigo"), y rechazar lo que pudiera considerarse como "poético", que puede llegar a ser el peor adjetivo en su obra: "Nosotros condenamos / -Y esto sí que lo digo con respeto- / La poesía de pequeño dios / La poesía de vaca sagrada / La poesía de toro furioso"; en clara alusión a Huidobro, Neruda y De Rokha. Y ha dicho preferir una poesía que podríamos calificar como periodística que se expresa en el "lenguaje de la tribu" por cotidiano que este pueda ser. Una poesía que incorpora conceptos, personajes y situaciones históricas y formulación de principios, más que intentos líricos. Una forma muy política o más de lo que podría pensarse y que se manifiesta, por ejemplo, en el "Coloquio del individuo" y otros textos que se constituyen en declaraciones de lo que el antipoeta cree y piensa. Opiniones y reflexiones sobre circunstancias políticas y sociales que definen las contradicciones de la sociedad chilena en una época especialmente conflictiva: los últimos cuarenta años del siglo $\mathrm{XX}^{2}$.

Esta tendencia ya estaba presente en sus escritos iniciales y en 1948, en el texto "13 poetas chilenos", escribe "Una poética":

\footnotetext{
Este rasgo debe ser comprendido al interior de una evolución literaria, pues en algunos poemas como "Hay un día feliz", "Se canta al mar" o la elegía a Violeta Parra, se observa cierta nostalgia por el ayer perdido, lo lárico y otros elementos propios de una poesía tradicional en los que no intenta degradar la realidad ni al hablante.

Ver, Javier Pinedo. "El pensamiento poético de Nicanor Parra... pp. 311-321.
} 
La función del artista consiste en expresar rigurosamente sus experiencias personales sin comentarios de ninguna especie. La función del idioma es para mí la de un simple vehículo y la materia prima con que opero la encuentro en la vida diaria (...) Finalmente, estoy en contra de la forma afectada del lenguaje tradicional poético. El lenguaje periodístico de un Dostoievski, de un Kafka o de un Sartre, cuadran mejor con mi temperamento que las acrobacias verbales de un Góngora o de un 'modernista' tomado al azar (Parra, Obras completas \& algo +, p. 691).

Parra opta por una narración con un hablante neutro y en ocasiones casi ausente:

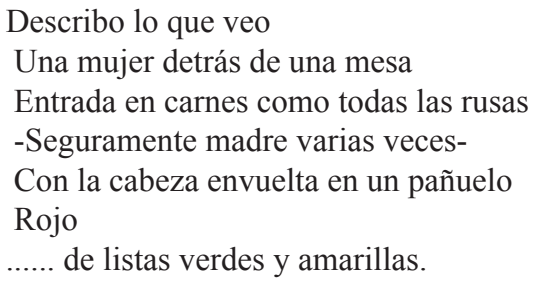

Tradicionalmente, la relación entre el lenguaje de la ciencia y el de la poesía, el de los conceptos y las imágenes, y sus variantes, las metáforas y las figuras literarias, fueron percibidas como métodos opuestos de interpretar el mundo: uno científico y el otro artístico. En la actualidad se tiende a acercar ambas posiciones cuando no a fusionarlas en un intento holístico, que utiliza tanto el raciocinio como la intuición. Es decir, recurriendo a todas las funciones del lenguaje, y no solo una (la poética), descritas por Jakobson.

Y esta relación creemos que es particularmente importante en un autor como Parra, de rigurosa formación científica pero cuya forma de expresión es la literatura y en su interior casi exclusivamente la poesía. Esto produce una serie de preguntas en las que es necesario meditar. ¿De qué modo esa formación inicial afectó en su manera de concebir el mundo como su manera de expresarlo a través de la palabra? ¿Desde dónde se plantean las preguntas que formula? En este sentido, podríamos afirmar, parodiando a Parra, que para él, poemas y conceptos unidos jamás serán vencidos. Método con el cual se busca responder preguntas filosóficas: ¿existe la realidad, cuál es el significado del tiempo, cuál es el sentido de la vida humana? ${ }^{3}$.

3 Parra trabaja con conceptos como socialismo, capitalismo, pop art, lucha de clases, mundo moderno, Círculo de Viena, ciencia, imperialismo, pueblos originarios, etc. Y recurre 
George Steiner, en La poesía del pensamiento, señala la imbricación de los géneros literarios y la presencia de la poesía en toda obra filosófica, incluso en el uso tan complejo de las metáforas, constituyendo lo que denomina "Denkende Dichtung" (2012).

Grínor Rojo anota una opinión de Menéndez Pidal que recuerda Luis Oyarzún, sobre la "capacidad de "intuición de lo real a través de lo sensible"” (2008, p. 88). Y con anterioridad, María Zambrano había planteado que en el pensar hispano funciona lo que denomina "razón poética" $(1939,1955)$, que anula la contradicción entre razón y poesía, y que explicaría el actuar de seres humanos (hispanos y variantes) que no pertenecen del todo al centro mundial del logos.

En el mismo sentido, pero aplicado a un caso concreto, Alain Sicard utiliza el concepto de "pensamiento poético" para estudiar las "visiones" de Pablo Neruda desde una perspectiva según la cual detrás de las imágenes del mar, los pájaros o del amor, Neruda nos está ofreciendo reflexiones similares a las que podríamos encontrar en un libro de ensayos pero enriquecido por imágenes poéticas. Habría una visión de mundo, una concepción oculta de lo real detrás de esas imágenes. Según Sicard, también es posible pensar desde la poesía.

Esta tesis tiene antecedentes también en algunos latinoamericanos, quienes postularon que la ausencia de expresiones lógicas y científicas en el continente no justificaba poner en segundo lugar a poblaciones humanas que no se expresan racionalmente al modo occidental, como Luis Alberto Sánchez cuando afirma:

Más que en estricta causalidad lógica - artificial, por lo demás, en toda historia-, el secreto de nuestra psique ha de rastrearse, frecuentemente, por indirecta ruta emocional y estética. Requiere de poetas tanto como de historiadores. Está envuelto en el misterio semántico de nuestro castellano criollo, mulato e indígena, absolvedor de nuevas esencias y forjador de palabras, ese castellano de los "americanismos" en que se han grabado las vivencias y las metáforas del aborigen en

con frecuencia a personajes históricos como el general Ibáñez, Allende, Frei Montalva, Milton Friedman, Nixon, Fidel Castro, Marcuse, Marx, Freud, Wittgenstein, Einstein, etc., lo que es poco habitual en la poesía chilena. En el mismo sentido construye sus poemas desde circunstancias históricas concretas como la Revolución rusa, la Guerra Fría, La Unidad Popular, entre otras. Es decir, una poesía muy anclada en su época histórica. 
la lengua importada y del español en un mundo distinto; se expresa en música, ritos, fiestas y danzas; se descifra en aquella misteriosa mano de 'mancegual' que incorporaba el patrón estilístico europeo de los monumentos coloniales, su propio lenguaje decorativo. Y por eso contra el hispanismo jactancioso y contra el indigenismo que querría volver a la prehistoria, la síntesis de América es la definitiva conciliación mestiza. El mestizaje americano consiste en mucho más que mezclar sangres y razas; es unificar en el tempo histórico esas disonancias de condición, de formas y módulos vitales en que se desenvolvió nuestro antagonismo(1962, p. 189).

De manera aún más explícita, Arturo Ardao en La inteligencia latinoamericana afirmó que aunque en América Latina no domina el uso de la "lógica" (al modo matemático), sí hay "inteligencia" (en la comprensión vital del mundo), que es otra manera, no científica, pero coherente, de aproximarse a la realidad. De alguna forma, estos últimos autores prefiguran el concepto de "Lebenswissen" con que Ottmar Ette ha definido a los saberes no necesariamente sistematizados que singularizan la literatura transferible de los pueblos (2009).

Por otro lado, hay que considerar las propuestas de Phillipe Sabot que analiza la estrecha relación entre literatura y mundo intelectual:

La littérature paraît ainsi offrir au philosophe une médiation commode entre la dimension du simple vécu et l'ordre de la conceptualité proprement philosophique, suivant l'idée que, dans les œuvres littéraires, l'expérience humaine se réfléchit et accède à une forme d'intelligibilité que la philosophie peut (et d'une certaine façon doit) recueillir en l'élevant à sa propre vérité.

Jacques Rancière, en "Política de la literatura", retoma la pregunta de Jean Paul Sartre, ¿Qué es la literatura?, polemizando sobre la autonomía de las obras literarias, pues en su opinión existe un nivel social que determina las condiciones de esa expresión. Lo más interesante para nosotros es que Rancière aborda la literatura francesa moderna desde la idea de que hay "un lazo esencial entre la política como forma de la práctica colectiva y la literatura como práctica definida del arte de escribir" (2011, p. 15).

En este contexto, la relación que establece Parra entre poesía, política y pensamiento nos parece aun más compleja pues por una parte desconfía de la poesía tanto como de la ciencia, al afirmar que esta finalmente conoce muy poco del funcionamiento del universo, y ese mismo criterio lo utiliza para la creación poética, con lo cual se vuelve un sujeto doblemente escéptico de toda 
posible interpretación de lo real, concluyendo en una soledad epistemológica radical: no hay ciencias que nos permita percibir lo real y, por otro lado, su desconfianza en la literatura y la poesía en especial lo obliga a escribir casi en fórmulas matemáticas recurriendo a silogismos o símbolos (como en el título Obras completas \& algo +), que producen poemas epigramáticos, con los que se burla de la tradición poética como de las interpretaciones racionales del mundo, incluidas las llamadas ciencias exactas, como por ejemplo, la estadística: "Hay dos panes. Usted se come dos. Yo ninguno. Consumo promedio: un pan por persona"4.

\section{CORTOMETRAJES Y CORTOCIRCUITOS QUE CONTIENEN EL MUNDO}

Algunos días después del recital en Talca pensé en algunos "Cortometrajes" en que he visto a Nicanor a lo largo de estos años y que marcan su vida y su obra. Tal vez exagero un poco. Tal vez recuerdo mal, pero estas memorias que voy a mencionar me serán útiles para comprender la situación mental del antipoeta y su creación literaria.

El primer cortometraje se produce con el regreso de Nicanor de los Estados Unidos en 1970. Es una historia conocida pero que es necesario traer aquí.

Nicanor Parra llegó muy complicado del viaje realizado en un año muy tenso, prototipo de la Guerra Fría, que se tradujo en la elección de Salvador Allende como Presidente de Chile y que concluyó con el asesinato del Comandante del Ejército, el general René Schneider, por un grupo de ultraderecha que intentaba evitar que Allende fuese elegido como Presidente por el Congreso en pleno, al no haber obtenido la mayoría absoluta y no existir la segunda vuelta.

Parra había sido invitado a participar en un encuentro internacional de poesía en Washington D.C., con el patrocinio de la Biblioteca del Congreso, y posteriormente a una visita a la Casa Blanca.

Varios días después de su regreso, Nicanor Parra toma café con un estudiante de literatura (que era yo y que lo admiraba), y le cuenta que mientras caminaba

$4 \quad$ En esta brevedad y economía de lenguaje puede haber cierta cercanía al humor y la ironía de las Greguerías de Gómez de la Serna, poco asociado a la antipoesía, y a veces muy cercano a ella. 
por la Casa Blanca, se abrió una puerta y apareció Pat, la mujer del presidente Nixon, que sin decir agua va, lo introduce en una habitación y le ofrece una taza de té. Una cuestión que parecía inocente se transformó, sin embargo, en un hecho político grave, pues Nixon representaba al feroz Estados Unidos y su impopular guerra en Vietnam, y sería el propio presidente Nixon y el matón Henry Kissinger (que alguna vez dijo que si Bolivia desaparecía nadie en el mundo se daría cuenta), quien le declaró la guerra a Allende ("That son of a bitch") y que terminó por provocar el Golpe de Estado de 1973.

Hay fotos que muestran a Parra casi como un profesor británico con una elegante pero gastada chaqueta de tweed, regalando un libro a Pat Nixon, con un aire irónico de sabio del Tercer Mundo, que no parece creer en nada de lo que está sucediendo a su alrededor.

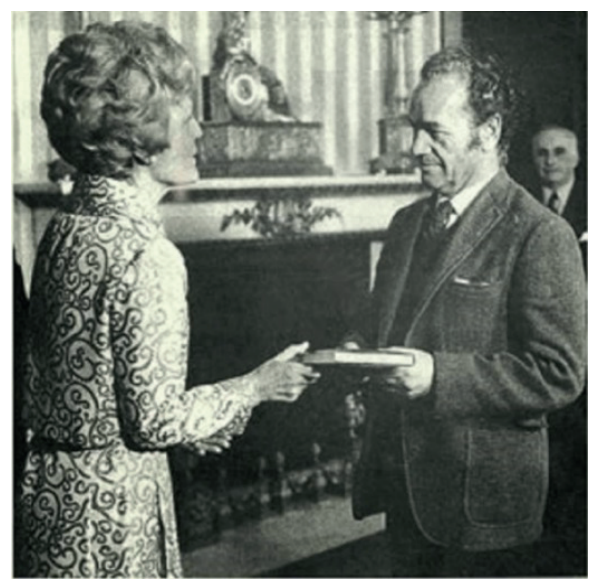

Pero, en aquellas circunstancias no había tés inocentes, y después de la visita a la Casa Blanca, muchos se pusieron en contra de Parra: Gonzalo Rojas, Carlos Droguett, Pablo de Rokha, Luis Merino Reyes, y especialmente Cuba y la izquierda chilena. Era una época muy distinta a la de hoy. Había que elegir entre los buenos y los malos 5 .

5 Uno de los pocos que lo defendió fue Luis Oyarzún, que vivía en Nueva York, y que publicó una carta en El Mercurio el 14 de julio de 1970 en la que escribe: "No tuve oportunidad de asistir a la importante reunión de poetas que se efectuó en la Biblioteca del Congreso de Washington en los primeros días de mayo. Menos todavía al té con Mrs. Nixon 
Algo similar había sucedido cuando Neruda almorzó con el presidente Belaúnde Terry en Lima en julio de 1966 y la izquierda lo acusó de traición. Hoy sabemos que Belaúnde fue menos malo que algunos de los presidentes anteriores o de los que vinieron después, pero era una época en blanco y negro.

Nicanor, tal vez más combativo que Neruda, responde con unos versos que parecen fragmentos de una declaración de principios:

Si el Papa no rompe con USA

Si el Kremlin no rompe con USA

Si Luxemburgo no rompe con USA,

Por qué demonios voy a romper yo.

La pregunta de Parra es inútil aunque fatalmente verdadera: él se compara con países o con poderes supraindividuales, y hay algo en el sistema que convierte a los individuos en esclavos, mientras que los Estados pueden mantenerse impunes en sus contradicciones. Es una crítica irónica en la que postula al individuo por sobre los sistemas políticos, planteando uno de los temas preferidos del antipoeta, la relación entre cultura y política y particularmente entre poder político y cultura literaria. Una relación en la que el antipoeta se transforma en un ser desvalido que fracasa:

Mendigo chileno

Agoniza entre 2 portaviones yanquis.

Su atención por favor.

Repito que a los pocos días de su regreso encontré a Nicanor en el restaurante "Los Cisnes" en la avenida Macul, frente al Pedagógico, sentado muy triste en un rincón. Tengo 23 años y Nicanor 56, pero acepta que lo tutee en parte por el aire juvenil que mantiene, y en parte porque soy estudiante de Federico Schopf que, en mi opinión, fue el primero que consideró a la antipoesía como objeto literario digno de análisis y reflexión, y Nicanor lo reconoce (1971).

Cuando le pregunté qué sucedía, me mostró un telegrama de Haydée Santamaría, la hermana de Abel, el joven revolucionario torturado y asesinado por Fulgencio Batista (que actuó como Caín) el 26 de julio de 1953. Se dice que a ese gran amigo de Fidel, Abel, la policía le arrancó los ojos antes de asesinarlo.

en la Casa Blanca que ha dado pretexto para someter a Parra en Chile, en Cuba y quién sabe dónde más a un verdadero juicio político-moral, como si hubiera participado en una acción de guerra en el Oriente asiático o fuera reo de un delito de alta traición (...)". Óscar Contardo 2014, p. 194. 
Después del triunfo de la revolución en 1959, Haydée fue nombrada directora de la prestigiosa y recién fundada Casa de las Américas de La Habana, y el telegrama decía que se abstuviera de viajar a Cuba como miembro del jurado de poesía de ese año al que había sido invitado.

El telegrama ardía en sus manos. El té con Pat Nixon lo había condenado. Por ingenuo, por inseguro, por lo que sea. En ese contexto de política en blanco y negro, nadie perdonaba un error de complacencia con el enemigo imperialista. Nicanor se había vendido al oro yanqui por una taza de té.

Nos quedamos en silencio y veo a Nicanor como en una foto, concentrado y abstracto, sometido a esos cortocircuitos eléctricos que le queman los fusibles y que provocarán los cortometrajes posteriores. No para de pensar.

Al rato tomó una servilleta y escribió como si fuera un telegrama: "Señora Haydée Santamaría. La Habana. Cuba. Stop. La historia me absolverá. Stop”. Aludiendo a la conocida frase que pronunció el propio Fidel Castro durante el juicio tras el asalto al Cuartel Moncada y que lo catapultó a la fama mundial como un abogado joven y patriota que con un puñado de valientes asalta una fortaleza militar y es derrotado. "La historia me absolverá".

En el caso de Nicanor es una amarga situación que debió provocar cortocircuitos múltiples: una cosa es asaltar con un grupo de revolucionarios un fuerte militar, fracasar y ser detenido y torturado, lo que a Castro le permitía pensar que esa acción era un acto de heroísmo nada reprochable y que la historia del futuro, comprendida de una manera jesuita-cristiana-martiana (no marxista todavía) tendría un orden teleológico y al final se impondrá el juicio (divino) que absolverá a los justos. Otra situación muy diferente es beber una taza de té en una habitación de la White House con la mujer del Presidente de los EE. UU., ser declarado culpable y pedir ser absuelto por la historia del futuro.

Son situaciones completamente diferentes, y sin embargo, Nicanor logró convencernos que el mundo de la Guerra Fría era absurdo y que los muros terminarían por caer, y que serían los habitantes de los postmuros, y no las divinidades de Fidel, los que lo absolverían a él. Nicanor igualó irónicamente ambas situaciones y puso la suya en un nivel histórico similar: "4 tazas de té que estremecieron al mundo", escribe aludiendo al famoso libro de John Reed ${ }^{6}$. 
Como fuente de inspiración, Parra escribió varios "Artefactos" con ese tema. En uno dice: "Cable de La Habana. Como chiste no pudo ser más triste". En otro: "Toda lucha fratricida. Todo pensamiento vano". Y otro: "Casa Blanca. Casa de las Américas. Casa de orates". Y aún: "A mí nadie me pisa los callos / A mí nadie me pasa a llevar / Aunque sea Fidel en persona / O la propia Unidad Popular"; "Cuba sí / Yankees también". Y este, tal vez, el más conocido:

Si fuera justo Fidel

Debería creer en mí

Tal como yo creo en él:

La historia me absolverá (Parra, Artefactos, 1972 ).

Vistas desde la "Caída del Muro de Berlín", y las actitudes pro capitalistas actuales de Rusia y Vietnam, para no decir del saludo en estos días de Barak Obama y Raúl Castro ${ }^{7}$, es fácil concluir que Parra percibió con mucha antelación que aquellas batallas (algunas más verbales que reales) de la Guerra Fría de los 60 y 70 no conducirían a nada, y que los extremos alguna vez terminarían por encontrarse. $\mathrm{O}$ aún, que el odiado "establishment" terminaría por absorber las críticas de sus enemigos, provocando, al revés, la desconfianza en las ideologías igualitarias y la confirmación de las posturas individualistas, como sucede en el presente. Lo cual, si lo pensamos bien, tampoco era tan difícil de imaginar, sino para los militantes más radicales de una de las dos posturas en conflicto: el socialismo y el capitalismo. Lo que era más difícil de adivinar era el suicidio de la propia Haydée Santamaría, un mismo 26 de julio de 1980, cuando la revolución cumplía veinte años.

Lo más importante, tal vez, es que este asunto provocó un distanciamiento de Nicanor hacia la Unidad Popular en el gobierno, la que como la mayoría de los movimientos que han intentado el cambio social en Chile y América Latina, tenía una parte de su origen en miembros de la élite burguesa, y esta situación causaba problemas a Nicanor Parra que provenía, él sí, del profundo mundo popular rural y esa diferencia la había hecho notar en múltiples entrevistas y poemas.

Es una de las causas de la distancia de Nicanor respecto a ese movimiento cuya cercanía en un comienzo debió ser más intelectual que real. Pero además, 
porque el sistema imperante en Chile permitía a personas como Nicanor Parra (o como Luis Oyarzún, Jorge Millas, Juan Rivano y muchos otros) ascender socialmente a través del trabajo universitario, lo cual no era nuevo, pues las clases sociales intermedias del siglo XIX utilizaron a la universidad como un modo de crecimiento social, como se observa en los casos de José Victorino Lastarria, Eusebio Lillo, y algunos extranjeros en Chile, Bello, Sarmiento, Domeyko, Philippi, entre otros, muchos de los cuales pudieron acceder a los puestos sociales más altos, como el venezolano Andrés Bello, quien alcanzó el cargo de Rector de la Universidad de Chile y el reconocimiento social para él y su familia, de modo similar al del científico polaco Ignacio Domeyko.

Lo mismo sucederá con los intelectuales de comienzos de siglo XX, quienes mantuvieron el estilo de ascenso social a través de un trabajo estatal ligado a la educación universitaria.

De todos ellos, el caso más evidente es el de Lastarria, cuya familia había perdido su fortuna y debió trasladarse a Santiago para estudiar e iniciar una profesión y una vida. Lastarria comprendió rápidamente que en el caso de un joven de provincia instalado en una capital socialmente jerarquizada como lo era Santiago, solo le quedaba destacarse en el estudio si quería ser aceptado, y esto es válido incluso para un personaje de novela como Martín Rivas, quien llegado a Santiago descubrió que para acceder a la bella Leonor Encina y a su familia, debía refrenar sus aspiraciones liberales y concluir la carrera de abogado (Subercaseaux 1981). Por esto, en el título de este artículo, he establecido una relación paródica con la obra más importante de Lastarria, sus Recuerdos Literarios, pues si Nicanor Parra provenía de un sector social más descendido y no transó (en un comienzo) con la ideología dominante sino que la subvirtió, posteriormente su rechazo a la alternativa socialista fue aún mayor.

Así, poco después del té norteamericano, Parra modificó sus estrategia y en la Revista Chilena de Literatura, número 1, otoño de 1970, publicó unos poemas titulados "Palabras obscenas", absolutamente contingentes, y en los que pone fin a cualquier posibilidad de cambio social, o de siquiera imaginar un futuro distinto, curiosamente en una época que comenzaba a soñar. El 4 de septiembre de ese mismo año será elegido Salvador Allende, quien hizo creer a muchos que sí era posible en Chile (no en cualquier parte) cambiar las estructuras económicas y sociales. Que Chile podía realizar lo que no habían podido muchos países por la vía del diálogo y el avance gradual.

La fuerza de esos poemas (de esos pensamientos) está en la potencia con que Nicanor grita que no cree en nada. Una declaración que expuesta en 
otras circunstancias no sería muy novedosa, pues en los 60 ya había muchos escritores que postulaban el mismo escepticismo, como Ionesco, Albert Camus y especialmente uno de los más leídos por nosotros, Paul Nizan, cuya novela Aden Arabie, comienza, "Tenía veinte años. No dejaré que nadie diga que es la edad más bella de la vida". Una novela que había sido publicada tempranamente en 1931, pero que se hizo famosa con su reedición en 1960, con un prólogo de Jean Paul Sartre, que en su primera etapa, la de la angustia, tampoco creía mucho en el futuro. Más tarde, Nizan y Camus serían grandes opositores a la política del Partido Comunista francés y se alejarían de Sartre.

En EE.UU., Hemingway, Arthur Miller, Truman Capote y más tarde los beatnik que optaron por vivir el presente, tampoco esperaron nada del futuro. Y lo mismo en el caso del irlandés Samuel Beckett, quien con su cara de águila desconfiada sabía que Godot no vendría ni hoy ni mañana, y para qué decir de los surrealistas anteriores y tantos otros. No, nadie podría sorprenderse de un poeta que en los años 60 gritara que no creía en nada. Ese no era el asunto. El asunto era que estábamos en un país (Chile), en que, en contra de todas las lógicas occidentales y orientales, una parte de él se había empeñado en asegurar que era posible reavivar el viejo sueño de cambiar la sociedad. La Unidad Popular, que tuvo un éxito más comunicacional que político, lo tuvo porque representó justamente un nuevo y gran entusiasmo frente al escepticismo que se levantaba tras el mayo del 68, la desconfianza en el comunismo soviético, el surgimiento del eurocomunismo e incluso las dudas en el modelo cubano.

En ese contexto (interno a Chile), en que una generación junto a algunos líderes más antiguos se jugaban por nuevas versiones del socialismo provocó el entusiasmo de las masas de izquierda, que creyeron que ahora sí se podía alcanzar el sueño pendiente desde los intentos reformistas del Centenario, del año 38, la fundación del FRAP y la propia Unidad Popular. Los poemas incluidos en "Palabras obscenas" son reveladores de esa descreencia y que con una impecable lógica señalan: "(...) yo propongo que todos nos hagamos católicos / o comunistas o lo que digan ustedes / es cuestión de cambiar una palabra por otra / yo propongo que purifiquemos el agua”. Este es solo un ejemplo, pero hay muchos en los que el que habla está en una situación de delirante dolor y desconfianza, con una fuerza similar a la del poeta cubano Heberto Padilla en su libro Fuera del juego (1968), que se enfrentó aisladamente al sistema instalado por Castro.

Esa es la grandeza y la degradación de la antipoesía, haberse puesto a gritar de dolor en un momento en que una parte del país creía que se abría 
una puerta en la historia para pasar a otra más justa y que era necesario celebrarlo con alegría ${ }^{8}$.

El asunto del té, sin embargo, no concluyó ahí, pues unos días después, en ese invierno del 70, encontré a Nicanor en los patios del Pedagógico sentado en un escaño que se apoyaba contra el edificio de ladrillos rojos del Departamento de Inglés, con una reproducción de la famosa foto de la aldea de Vietnam en la que unos niños corren para salvarse de las bombas de Napalm que incendian sus casas de paja. Esta es la imagen que sostenía:

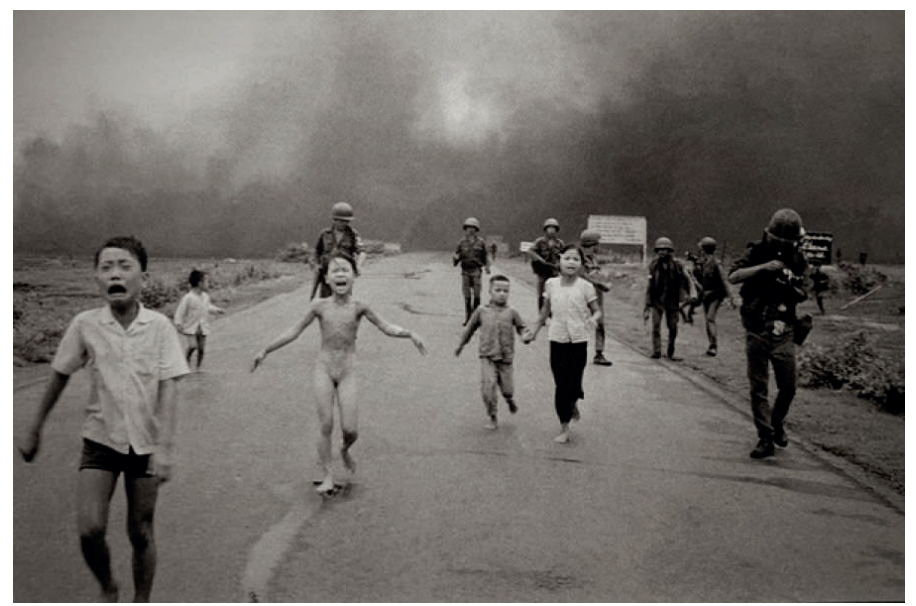

Nicanor estuvo horas con esa foto, aumentada al tamaño de un afiche, en sus rodillas. Lo veo como un hombre serio, pétreo, abstracto, mudo, interferido, queriendo decirles a los estudiantes que pasaban que él tenía su corazón, que no era un traidor a la izquierda ni a nadie, pero que le parecía que el mundo de la Guerra Fría era absurdo y no duraría. Que no apoyaba esa guerra ni ninguna otra. Yo le creí.

La foto muestra a una niña de nueve años, Kim Phuc, huyendo de su aldea Trang Bang, al sur de Vietnam; aunque nosotros siempre pensamos que se trataba de la aldea de My Lai, donde se produjo una de las mayores masacres de civiles incluyendo niños y mujeres.

8 La Unidad Popular concebida como una fiesta colectiva está muy bien expuesta por Tomás Moulián en Conversación interrumpida con Allende, 1998. 
Es una de las muchas aldeas carbonizadas por el ejército norteamericano, y ahora que poseemos tantos recursos de información sabemos que el paso del ejército dejó un país destruido y un pueblo mutilado como pocas veces antes se había visto.

En el mismo contexto de la Guerra Fría, Parra había visitado Moscú en 1958, y más tarde en 1963 dio recitales en esa ciudad y en Leningrado. En 1965 se traduce al ruso una antología de sus poemas a cargo de Margarita Aliguer. Y en 1967 publicó "Canciones rusas" en la Editorial Nascimento de Santiago.

Parra, heredero de una familia comunista o al menos de izquierda, no tenía mucho espacio de maniobra estratégica pues debía responder a esos códigos políticos y culturales de tanta presencia en un país como Chile, por lo que no estaba en condiciones de tomar partido o solo desde una posición que había expuesto en el Soliloquio del Individuo (1954), expresando que finalmente en este mundo no hay inocentes absolutos y que los culpables están en todas partes. Lo único que podía hacer era regresar dando vueltas y vueltas como el tocadiscos de Aquiles y la Tortuga, al comienzo de la historia.

Yo soy el Individuo.

Mejor es tal vez que vuelva a ese valle,

A esa roca que me sirvió de hogar,

Y empiece a grabar de nuevo,

De atrás para adelante grabar

El mundo al revés.

Pero no: la vida no tiene sentido.

De modo similar a los versos mencionados anteriormente, también en estos observamos una declaración de principios, más que un objeto lírico. El que habla es más un pensador, decepcionado y solo, que un poeta a la usanza de tristes románticos privilegiados. En estas circunstancias, la literatura y el arte no pueden cumplir ninguna salvación ni función estética: "Todo es poesía / Menos la poesía”.

\section{CORTOMETRAJE MEXICANO}

No estuve presente en este episodio, me lo contó el mismo Nicanor, y trata de una improvisada entrevista que dio al bajar del avión en México, donde había viajado para recibir el Premio Juan Rulfo que la Universidad de Guadalajara 
inauguraba en 1991. Al bajar, lo esperaba una nube de periodistas que le preguntan cuáles eran, en su opinión, los dos mejores poetas mexicanos.

Parra guarda silencio. Es una pregunta capciosa y fatal, el antipoeta cae en la trampa y responde: "Ramón López Velarde y Xavier Villaurrutia".

"En ese momento perdí el Nobel", me dijo. "No mencioné a Octavio Paz que era a quien le consultaban desde Suecia para obtener información sobre los candidatos futuros, pues Paz había recibido el Premio Nobel de Literatura en 1990 y tenía una vara muy alta en Estocolmo".

Creo que más allá de sus ironías sobre el Nobel ("En Chile es de mal gusto llegar a los 70 sin el Nobel"), ese momento lo persiguió durante mucho tiempo: aprender a responder con precisión en momentos críticos.

Parra asume la lección y la aplica, cuando lo visitamos mucho después en Las Cruces con Federico Schopf, quien en los días previos a la visita había respondido una encuesta de El Mercurio sobre cuál era el mejor poema escrito en Chile en el siglo XX, Schopf había elegido "Galope muerto" (1935) de Neruda.

Ese mismo domingo en que apareció el artículo, llegamos a Las Cruces y se veía que Parra estaba ofendido porque Federico no había mencionado "El hombre imaginario" (1985) y se lo dijo. Schopf se defendió: no tenía opción, era un solo poema y no podía dejar fuera a Neruda.

Parra contraatacó: "En este caso el hombre superior del Tao elige dos poemas". Que fue lo que él no hizo en México al no elegir no a dos sino tres: López Velarde, Villaurrutia y Octavio Paz. Es un cortometraje que probablemente continúe dando vueltas en la mente del antipoeta.

\section{6. (LARGO) CORTOMETRAJE ARGENTINO}

El viernes 31 marzo de 2006 vamos con Ricardo Piglia y Federico Schopf a visitar a Parra a Las Cruces. Piglia está en Chile como ganador del Premio Iberoamericano de Letras, José Donoso, que organizo año a año. Como siempre, nos recibe muy bien y con cierta escenografía de libros previamente preparados sobre la mesa, entre los que se destacan algunos de Shakespeare y los del visitante argentino.

Parra estima mucho a Piglia, quien había sido mencionado para escribir el prólogo de las Obras Completas de Nicanor en Galaxia Gutenberg, que al final lo compuso el propio Federico y que fueron publicadas justamente 
ese año. Además, Piglia era valorado y reconocido como un nuevo estilo en la novela argentina y un hombre con una erudición única en estos tiempos de tinieblas culturales. Piglia parece normal. Nicanor Parra, en cambio, está dominado por cortocircuitos y cortometrajes que le otorgan un aire de genialidad abstracta.

Esta vez habla mucho, cuenta historias, anécdotas literarias con simpatía y humana profundidad. Camina alrededor nuestro con un cuaderno en el que escribe algunas de las frases que se pronuncian durante la conversación. Le encanta una de Federico: "Es peligroso morir en un accidente", que rápidamente escribe en su cuaderno y lo repite una y otra vez.

Con humor macabro, alguien dice: "Suicídate. No te arrepentirás", que Parra anota en su cuaderno en medio del gozo de haber captado un endecasílabo, pues últimamente cuenta el tamaño de las frases que se mencionan. Está obsesionado con los endecasílabos que surgen espontáneamente y los cuenta con los dedos como si fuera un niño en un examen de matemáticas. Como el famoso: "Se reparte jamón a domicilio".

Luego nos habla de Shakespeare, del que escribe una traducción de Hamlet en su propio estilo. Sobre la mesa tiene muchos libros del inglés, así como traducciones diversas. Parra se pega con una palabra, que no recuerdo pero podría ser "Ache", dolor.

"Ache" es un término muy antiguo, nos dice, anterior al inglés isabelino, y quiere saber su origen y significación completa. Cree que el primero que lo utilizó fue un tal Sir Richard Edwards, al que le ha seguido la pista. En Hamlet, Shakespeare la utiliza de este modo:

To be, or not to be, that is the question-Whether 'tis Nobler in the mind to suffer/ The Slings and Arrows of outrageous Fortune,/ Or to take Arms against a Sea of troubles, / And by opposing, end them? To die, to sleep - /No more; and by a sleep, to say we end / The Heart-ache, and the thousand Natural shocks That Flesh is heir to? 'Tis a consummation / Devoutly to be wished. To die, to sleep/...

De pronto exclama, "Vamos a comer", pero antes y sin previo aviso comienza a hablar de Borges, a quien Piglia como buen argentino cita continuamente y se refiere a él como a un ser superior. Que lo es. Pero Parra, como es habitual en su obra, baja a Borges del pedestal y lo pone en la calle, como se verá a continuación.

Parra nos cuenta que fue invitado a Nueva York, a una reunión sobre la ciudad del futuro, el año 1969. En principio la rechazó por no corresponder 
a su tema, pero se la vuelven a reiterar señalando que también asistirán escritores, artistas y no solo arquitectos.

Allí, cerca del Bronx, en un edificio cuyo nombre no recuerdo, se reúne un grupo importante de intelectuales de diversos países. En un momento de la reunión habla Jorge Luis Borges de manera brillante sobre literatura y mundo. Pero, su frase final lo condena. "El que ha hablado, dice, es un conservador argentino".

Se produce una gran conmoción y un silencio incómodo. La palabra conservador no es la más apreciada en los años 60 y menos en esas circunstancias. Parra no puede permanecer callado y tomando el micrófono le dice a Borges: "Señor Borges, quiero preguntarle, qué piensa un conservador argentino de la guerra de Vietnam. Qué piensa que este Congreso se esté realizando a metros del ghetto de Manhattan. Qué piensa de la política llevada adelante por el imperialismo norteamericano".

Borges responde: "Un conservador argentino es un escéptico. Nada más".

Parra insiste sobre qué piensa un escéptico argentino de la guerra de Vietnam, del ghetto de Manhattan, del imperialismo norteamericano.

Borges, toma el micrófono y moviendo su cabeza como si mirara a su alrededor con sus ojos no videntes, pregunta con cierto desprecio: “¿No sé quién me hace estas preguntas?". "Parra”, responde, "Nicanor Parra". "Bien, señor Parra, qué quiere que le diga de Vietnam si yo nunca he estado allí".

Esto provocó la ira de los presentes que comienzan una ensordecedora rechifla contra Borges, y en un momento es tanta la rabia del público, que Parra distingue a un muchacho de pelo largo y dura mirada comprometidamente progresista que avanza hacia Borges gritando, "Yo a usted le rompo la cara con un ladrillo".

Borges, sospechando la situación mueve su bastón de ciego tratando de defenderse de invisibles atacantes. La cosa es grave y Parra le pregunta a una mujer a su lado, quién es el que avanza. La mujer responde, que es Miguel, un muchacho de su Facultad. Entonces Parra toma el micrófono y grita: "Miguel, basta". Lo que hace que el joven efectivamente se detenga evitando el golpe a Borges.

Más tarde, durante el cóctel, el secretario personal de Borges, Norman di Giovanni, llama a Parra a un lado y le pide que acompañe a Borges a su departamento para conversar el tema. Que lo está esperando abajo en el auto.

Parra baja, se monta en el auto y se da cuenta de que Borges no le habla ni le pregunta nada, como si estuviera en otro lugar. El auto avanza, llegan al 
departamento que la editorial le ha puesto al argentino, y allí este le dice que debe dormir siesta. Parra permanece solo con el secretario que en un momento mira a Parra y le dice que está mal vestido, que parece un pordiosero, y que se ofrece para acompañarlo, mientras Borges duerme, a la mejor tienda de Nueva York, a comprar al menos una corbata nueva.

Así lo hacen, llegan a una gran tienda, y "yo acepto una corbata, que me regala Norman". Regresan al departamento, al rato despierta Borges, y habla con Parra algo general y luego le dice que deben ser amigos, y que los amigos en Argentina beben vino con las copas cruzadas entre los brazos, lo que hacen luego de descorchar una botella, y a continuación, Borges concluye que en Argentina, los amigos intercambian corbatas.

Borges se saca la suya y se la entrega a Nicanor, que le entrega la nueva y cara recién comprada. Todo es muy sorprendente para Parra que se deja llevar por una insólita situación que le recuerda la literatura de Lewis Carroll.

Por la tarde regresan al Seminario. En la puerta de entrada un grupo de adherentes de Borges lo están esperando y gritan en su defensa. El Seminario ofrece una cena americana a los asistentes y a la hora de los postres, Frank MacShane de la University of Columbia, quien escribió una historia sobre Chandler y otra muy buena sobre Ford Madox Ford, "se me acerca y me dice que los organizadores han decidido que dos poetas lean dos poemas cada uno. Los elegidos son: Borges y Parra".

Borges comete un nuevo error y recita un soneto, forma poética poco apropiada para la ocasión, y el público aburrido apenas aplaude. Parra lee "La víbora" y se gana la audiencia. Borges lee otro poema de poco valor. Parra permanece sentado y no lee más.

Ricardo Piglia no puede creerlo y alega que nunca había escuchado esta historia. Federico la corrobora, al menos en la escena de Borges moviendo su bastón de ciego delante de su cara para evitar ataques. Piglia está muy sorprendido de esta versión que definitivamente baja a Borges del Olimpo.

Nicanor agrega que la historia continúa, pues en 1976, cuando Borges vino a Chile a recibir la famosa medalla de Pinochet, el Director de Estudios Humanísticos de la época, Mario Góngora, le pidió a Parra presentar a Borges; Nicanor rechaza la oferta y sugiere a Enrique Lihn. Góngora señala que ya habló con él y también se disculpó. "Al menos asiste a la ceremonia", le ruega Góngora. "Eso sí”, afirma Parra.

Realizado el homenaje y de regreso a su casa en La Reina, Enrique Lafourcade lo llama por teléfono para invitarlo a cenar con Borges. Parra 
asiste y allí recuerda la historia de Nueva York, que es aprovechada por Lafourcade para escribir un artículo en El Mercurio en el que invierte la narración señalando que Parra le pidió la corbata a Borges y se quedó con ella.

Estamos en silencio. Cada uno está analizando el asunto y sacando sus conclusiones. La mudez se rompe cuando una voz que es la de Parra exclama: "Eso es todo. Así termina el cuento", y regresa a un profundo mutismo, tan interferido como aquella vez en Talca, tal vez poseído por los mismos cortocircuitos.

De pronto vuelve a repetir: "Vamos a comer", todos nos levantamos y nos dirigimos al "Caleuche", cerca de Las Cruces, donde nos sentamos a una mesa desde la cual vemos el mar que al reventar contra las rocas se levanta transformando el azul del cielo en blanco de espuma.

Parra está con tan buen humor y apetito que pide machas a la parmesana $\mathrm{y}$ algunas piezas de congrio frito, ensalada chilena, vino caro, y de pronto se pone a recitar de memoria unas baladas inglesas del siglo XVIII, pues aprovechó, nos dice, las estadías en Brown y en Oxford para leer esas baladas como la que ahora está recitando. La última es una balada triste que narra el cariño de un muchacho pobre de los barrios marginales y sucios de Londres que por medio del amor hacia su amada logra iluminar ese mundo de basura y hollín, con el sol de la palabra bien dicha. Parra ama el inglés y la literatura inglesa: "Qué sería del mundo sin Inglaterra. Que sería de Inglaterra sin Shakespeare"; y utiliza un inglés correcto y académico, bien masticado, haciendo gala de memoria y virtuosismo verbal.

Y a continuación, y ante la sorpresa y complacencia nuestra, recitó en griego clásico las primeras estrofas de La Ilíada de Homero, en la que se invoca a la divinidad:

Canta, oh diosa, la cólera del Pélida Aquiles; cólera funesta que causó infinitos males a los aqueos y precipitó al Hades muchas almas valerosas de héroes, a quienes hizo presa de perros y pasto de aves -cumplíase la voluntad de Zeus- desde que se separaron disputando el Atrida, rey de hombres, y el divino Aquiles.

Luego repite, tapándose la boca con la mano como si estuviera confesando un secreto: “... a quienes hizo presa de perros y pasto de aves”. Nos queda mirando profundo y abstracto esperando alguna réplica ante ese monumento literario que ha puesto en la mesa, y sin esperar respuesta nos lanza que la literatura occidental está en decadencia después de Homero. Salvo algunas excepciones, dice, y vuelve a reír sospechosamente. 
Parra ha querido manifestarnos que no todo es chiste en la antipoesía, y que él sabe más literatura de lo que él mismo dice saber. Así, mostrando una cultura que el antipoeta niega, recita un poema muy irónico de Serguéi Esenin, en idioma original y luego traducido por él mismo, en el que Esenin realiza un juego de palabras con la idea de depositar el voto de una elección política en una "urna", palabra que en ruso se puede utilizar también como "escupidera", por lo que el poema se puede leer como un llamado a los ciudadanos de participar de las elecciones pero también como un llamado a dejar el voto en medio de los escupitajos a la entrada del metro de Moscú.

Luego, recita a Baudelaire en un francés voluntariamente exagerado, y cuando creíamos que todo había terminado menciona a Andrés Fidalgo, un desconocido poeta del norte argentino. Piglia algo ha escuchado de él, pero no recuerda nada en particular. El resto de nosotros no lo conoce, pero Beba, la mujer de Piglia, dice haberlo leído alguna vez. Entonces, casi mágicamente, Parra dice que recuerda un poema de Fidalgo, pero le cuesta traerlo a la memoria. Se concentra, pasa un rato y comienza a escribir en unas servilletas que conservo, los distintos versos. A veces se detiene, otras avanza, hasta darle forma final al poema que se denomina "Folclóricas", aunque Parra prefiere otro título: "El poeta como guía turístico". Nadie lo puede creer. Tiene el poema casi completo, un poema, muy cercano a la antipoesía. Reproduzco esos versos de Fidalgo:

\section{Folclóricas}

Arriba, arriba, La Quiaca,

Puesto del Marqués, Tres Cruces,

la Puna fantasma.

Después, Humahuaca

el pueblo importante

rodeado de nada.

Hasta Bolivia y Chile

ciento treinta casas;

por el este,

la salida del sol y Salta.

Hacia abajo,

el oasis de Tilcara

reverberando en medio

de polvaredas y pucaras;

la botica, los cerros...

$\mathrm{y}$ otra vez nada. 


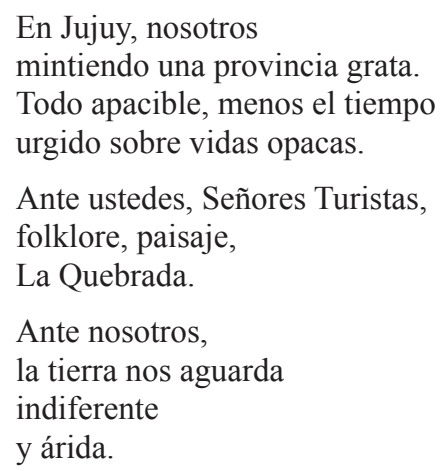

Es un poema tal vez de menor importancia si lo comparamos con los que hemos escuchado antes, pero por alguna razón ha impactado a Nicanor que lo aprendió de memoria. Me pareció que en este y algunos otros poemas recitados, y más allá de la diversidad, había algo común: son poemas narrativos, tristes, irónicos, algunos breves, cercanos, tal vez, a Pezoa Véliz, autor que parece interesarle al antipoeta.

$\mathrm{Al}$ recordar aquella tarde ahora me doy cuenta de que no fue una escena reducida a algunas imágenes de un cortometraje sino un largo metraje. Parra se disfraza de no conocedor, pero sabe mucha poesía y aun de memoria, y ese fue el mensaje que nos quiso entregar: no se equivoquen, detrás de la antipoesía hay mucha lectura y mucho trabajo y no se trata solo de una cuestión de ingenio.

Más tarde, de regreso a su casa en Las Cruces, Nicanor se enfrenta con Federico a propósito del prólogo que este ha escrito para sus obras completas, en la edición de Ignacio Echevarría. "Es muy bueno, le dice, pero tu tesis final es que la antipoesía se farandulizó, y eso no es correcto".

He vuelto a leer esas últimas páginas de Schopf: "La risa es el velo que, en la antipoesía, cubre cuanto puede este panorama, es el mecanismo de evasión permanente producido por la industria mediática del entertainment, pero también, y sobre todo, la renovada fuerza de liberación que trasmite la antipoesía como recurso para sobrevivir, para enfrentar lo insoportable y afirmar el deseo y los derechos de la vida". Y un poco más adelante cerrando el prólogo, dice el profesor Schopf: "Algunos momentos de su desarrollo -visto como un conjunto abierto, como una serie discontinua de resultados-se sostienen en el límite entre el arte y el no arte, fragilizan (corroen, socavan) la distinción tradicional entre poesía y no poesía, acaso contribuyan a anunciar otra vez, epocalmente, el fin del arte" (Schopf “Genealogía...”, p. CXXXI). 
Seguramente estas últimas líneas fueron las que no le agradaron a Parra, el fin del arte, así como la palabra entertainment, aunque es curioso porque Parra se burló justamente del arte del siglo XX y en algunos momentos del arte de todas las épocas ("basura greco latina"), por lo que no debía haberle herido este comentario.

Es un tema crucial y al que la antipoesía ha estado muchas veces en peligro de caer, el de su exitoso reconocimiento, pero el de su autotransformación, al mismo tiempo, en un juguete literario, ingenioso y sin trascendencia, como si la antipoesía fuera la (pícara e ingeniosa) respuesta chilena a los conflictos de la emancipación individual y social de los años 60 y 70 . El propio antipoeta percibió este peligro al definir la antipoesía como: “¿Un temporal en una taza de té?".

Lo que escribió Federico es una opinión que de alguna manera ya la habían pensado otros, pero era necesario tener un conocimiento muy profundo de la poesía chilena para señalar ese peligro, que en mi opinión no tiene nada de malicioso, sino que solamente intenta desmarcarse de tanto elogio sin fundamento. Señalar ese peligro, y Parra lo percibió, o tal vez ya lo había percibido, y entonces su famosa frase: "¡Cuidado, con Federico nunca se sabe!”.

Federico, sintiendo el peso y la mirada de Parra, trata de defenderse y busca por el lado tangencial alguna explicación, señalando que no es exactamente así, aunque algún sentido parece tener ese comentario suyo. Federico no puede negarlo pero tampoco exponerse. La situación se vuelve algo tensa.

Entonces, como un boxeador que pelea con su propia sombra, Parra señala que toda la cultura se ha vuelto una farándula, nadie puede evitar su contaminación. Pero, la pregunta fundamental, dice, es saber qué viene después de la farándula, como si también él ya hubiera reflexionado desde mucho antes sobre el tema. Y hablando solo para sí añade que después de la farándula vienen "las variables ocultas". Estamos pasmados ante su monólogo y agrega: "Podemos confiar en la ciencia, pero sólo en un noventa y nueve coma nueve, nueve, nueve por ciento, pues hay un cero coma cero, cero, cero uno por ciento, en que la ciencia no puede decir nada. Por la simple razón que la ciencia sólo habla de las variables que se pueden observar, pero existe, dice, un pequeño margen, las llamadas "variables ocultas", realidad en la que nadie puede pronunciarse con exactitud. Eso es lo que viene después de la farándula".

Creo que yo soy el único que ha escuchado su explicación. El resto se ha marchado. Me quedo con Parra que me mira muy lejano y muy cercano, una vez más como si estuviera solo, no en Las Cruces sino en el universo. 
Esta actitud de desconfianza en las verdades absolutas influyó en su generación, y Jorge Millas, por ejemplo, en uno de sus libros (1960), en el que analiza la realidad chilena desde el concepto de "espíritu" oponiéndose al materialismo filosófico que dominaba por entonces, introduce un verso de Nicanor Parra como epígrafe: "El espíritu sopla como puede" indicarnos que incluso aquello que pensaba como más estable, el espíritu, resultaba frágil y limitado.

\section{CONCLUSIONES}

Parra es un antimoderno absoluto que no cree ni en lo racional, ni en lo real, según la afirmación hegeliana, ni en la conciencia del ciudadano, ni en el Estado, ni en el progreso, ni en las demás creencias del proyecto ilustrado. Parra efectivamente cultiva un piojo en su corbata. Él ve el absurdo del mundo, donde solo existen rebeliones individuales. Disconformidad. No aceptación. Esclavitud. Para siempre. Ya lo he dicho en otras ocasiones, la antipoesía nos vacunó contra las (falsas) utopías y es uno de sus méritos mayores.

Parra sumó la rabia que sentía por el mundo moderno a la rabia contra la Unidad Popular, contra la izquierda y contra el propio Salvador Allende. El riesgo fue acercarse peligrosamente, aunque fuera por un breve tiempo, a la dictadura militar que se inició en 1973, tal vez más por despecho que por verdadera convicción, y aceptó la Dirección del Departamento de Matemáticas en el Instituto Pedagógico, brutalmente allanado previamente por los militares. Un hecho que se transformó en el gran cortocircuito del horror instalado en Chile y más tarde en el propio Parra.

Más allá de sus errores y sus aciertos podemos suponer que hoy para el antipoeta no existe ciencia ni filosofía en qué confiar, ni poesía que escribir. Hay cortometrajes mentales esperando en la oscuridad.

Un testigo, un observador comprometido con un país que para el antipoeta no ha estado a la altura de lo que se esperaba, como si su destino fuera vivir en un fatídico "eterno retorno" nietzscheano actualizado por Mircea Eliade (que tanto se leía en los 60) y graficado una vez + en el viejo tocadiscos que hacen girar, mientras se persiguen Aquiles y la Tortuga. El antipoeta intentó creer en algo, no lo alcanzó y permanece como una voz renovadamente

$9 \quad$ No conocemos el origen de ese verso de Parra ni de donde lo obtuvo Millas. 
insatisfecha, profundamente crítica y, quizás, cada vez más aislada de una realidad que lo supera en absurdidad.

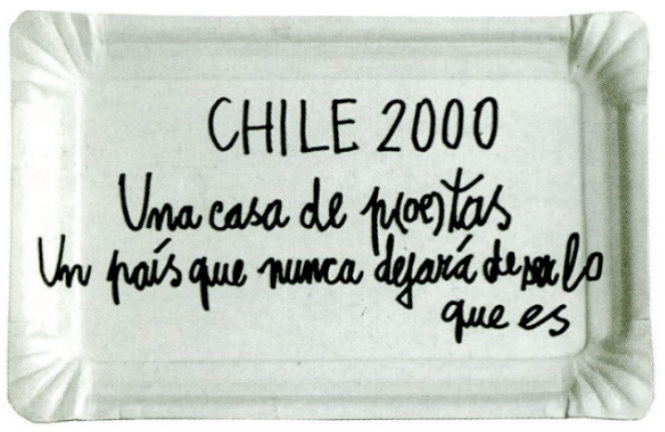

\section{BIBLIOGRAFÍA}

Ardao, Arturo. La inteligencia latinoamericana. Montevideo, 1987.

Contardo, Óscar. Luis Oyarzún. Un paseo con los dioses. UDP, 2014.

Ette, Ottmar. "Saber vivir y saber sobre /vivir". Del macrocosmos al microrrelato. Literatura y creación - nuevas perspectivas transreales. Guatemala: F\&G editores, 2009.

Millas, Jorge. Ensayos sobre la historia espiritual de Occidente. Santiago: Universitaria, 1960.

Moulián, Tomás. Conversación interrumpida con Allende. Santiago: LOM, 1998.

Parra, Nicanor. Artefactos visuales. Santiago de Chile: Fundación Telefónica, 2001. Obras completas \& algo +. Barcelona: Galaxia Gutenberg, 2006.

Pinedo Javier. "El pensamiento poético de Nicanor Parra en el contexto político-cultural de Chile en los últimos años". Poesía hispanoamericana: de la vanguardia a la postmodernidad. Lima: Univ. Nacional de San Marcos, 2012.

Rancière, Jacques. Política de la literatura. Buenos Aires: Libros del Zorzal, 2011.

Rojo, Grínor. "Luis Oyarzún lee a Gabriela Mistral mientras yo leo a Luis Oyarzún leyendo a Gabriela Mistral”. Las armas de las letras. Ensayos neoarielistas. Santiago: LOM, 2008.

Sabot, Philippe. Pratiques d'écriture, pratiques de pensée. 2001. Philosophie et littérature. Approches et enjeux d'une question, 2002.

Sánchez, Luis Alberto. Examen espectral de América Latina. Buenos Aires: Losada, 1962.

Schopf, Federico. "Introducción a la antipoesía". Prólogo de Poemas y Antipoemas de Nicanor Parra. Santiago: Nascimento, 1971.

"Genealogía y actualidad de la antipoesía: un balance provisorio". Prólogo a Nicanor Parra, Obras completas \& algo +. Barcelona: Galaxia Gutenberg, 2006. 
Steiner, George. La poesía del pensamiento. Madrid: Siruela, 2012.

Subercaseaux, Bernardo. Lastarria: Ideología y Literatura. Santiago: Aconcagua, 1981.

Zambrano, María. Filosofía y poesía. 1939, y El hombre y lo divino. México, 1955. 